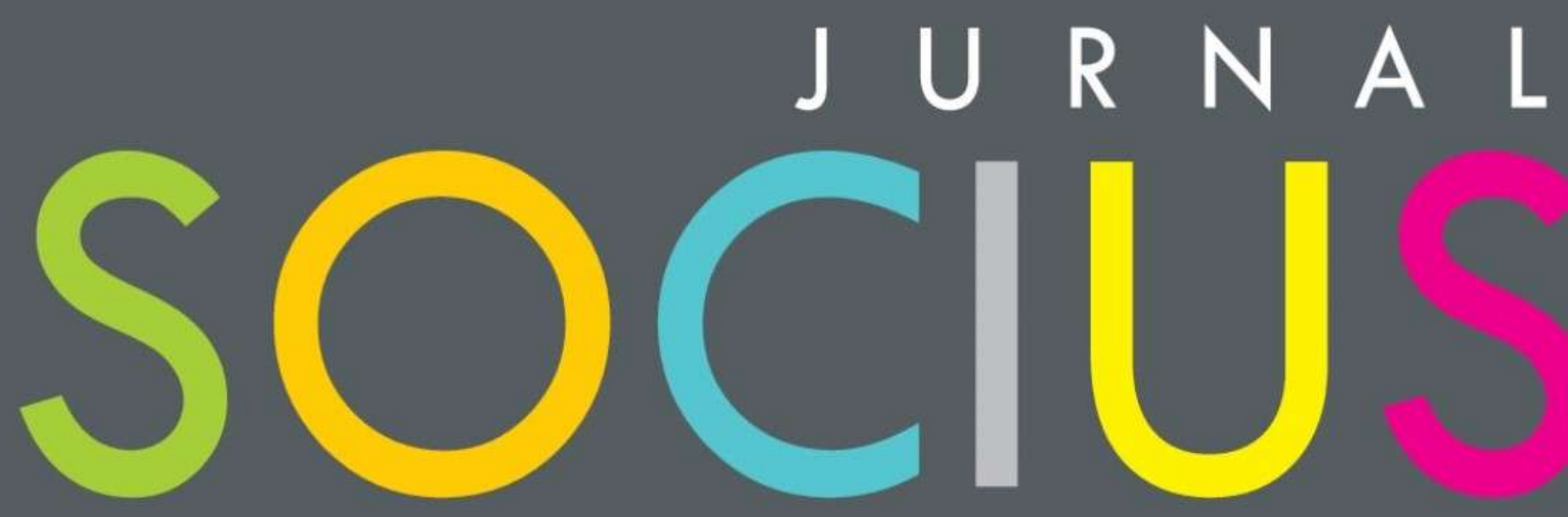

Journal of Sociology Research and Education

DITERBITKAN OLEH :

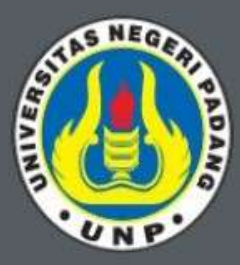

LABOR JURUSAN SOSIOLOGI FAKULTAS ILMU SOSIAL UNIVERSITAS NEGERI PADANG

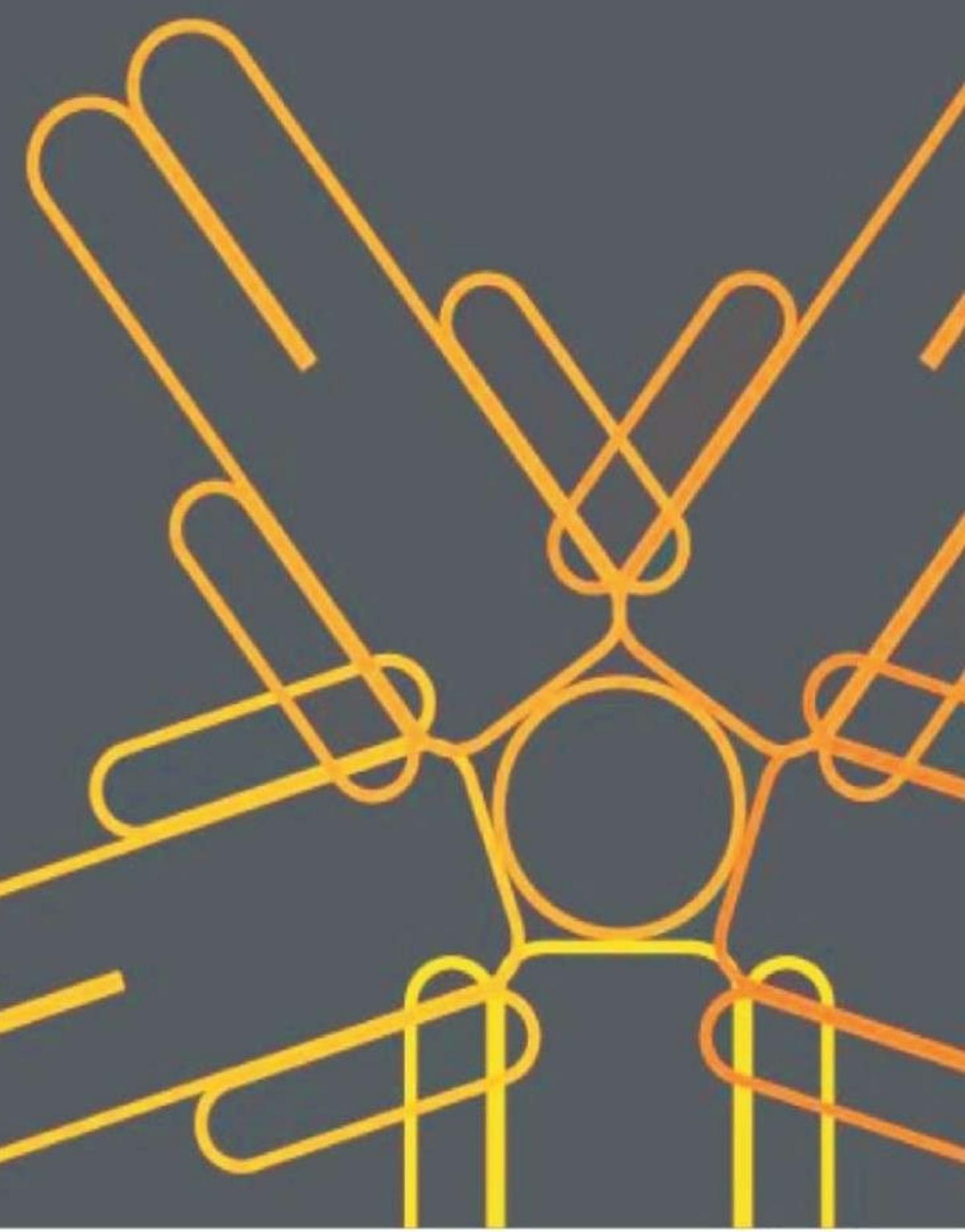




\section{SOCIUS}

Vol. 5, No.2, Th. 2018

ISSN : 2356-4180 (cetak)

2442-8663 (online)

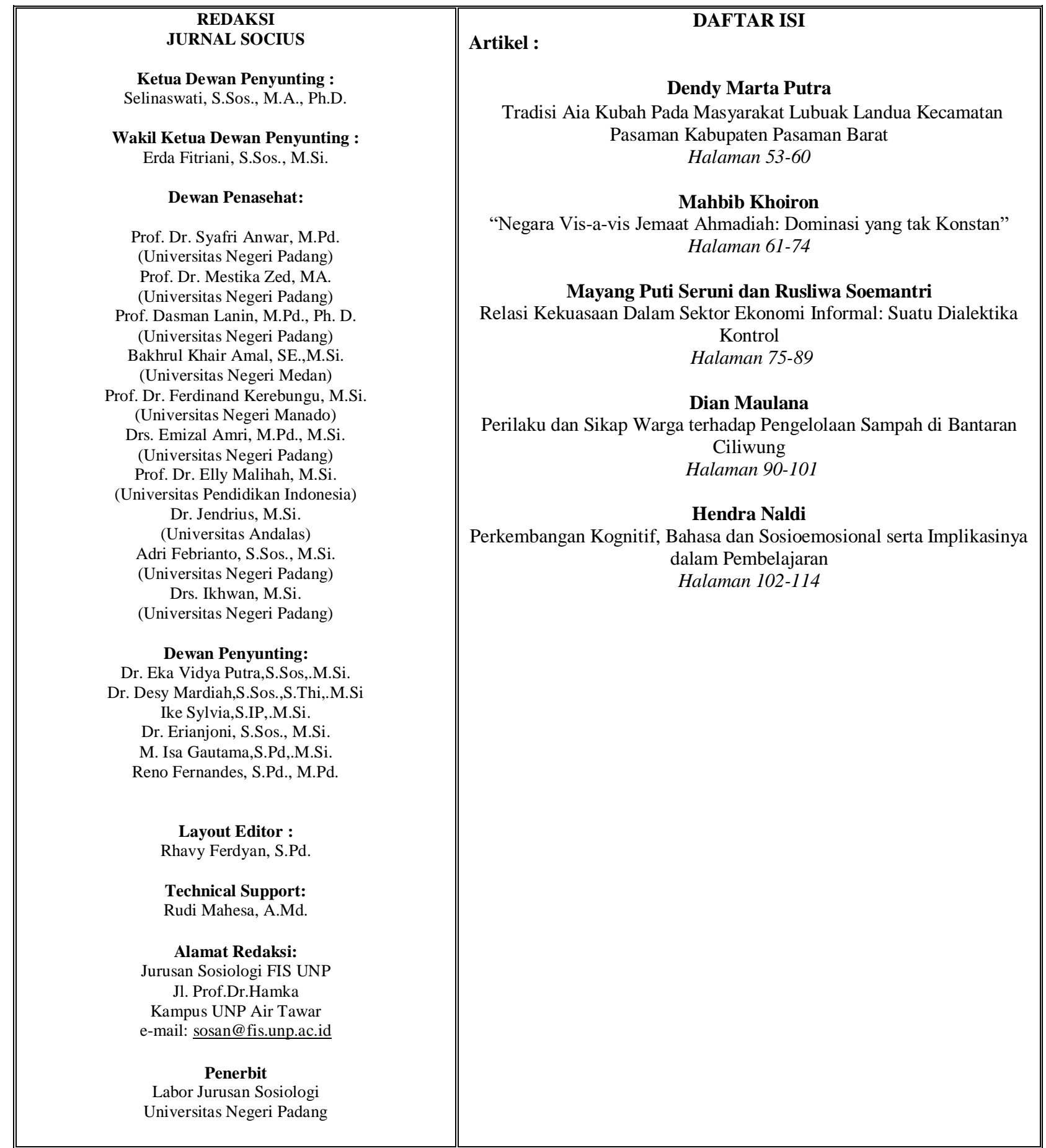




\title{
PERKEMBANGAN KOGNITIF, BAHASA, DAN PERKEMBANGAN SOSIOEMOSIONAL SERTA IMPLIKASINYA DALAM PEMBELAJARAN
}

\author{
Hendra Naldi \\ Universitas Negeri Padang \\ Email: hendranaldi69@yahoo.co.id
}

\begin{abstract}
Abstrak
Tulisan ini menganalisis proses perkembangan pembelajaran yang dilalui anak yang dibagi dalam tiga tahapan penting yakni perkembangan kognitif, perkembangan bahasa dan perkembangan sosioemosional. Karena setiap anak memiliki karakteristik dan keunikan tersendiri, maka dalam tiga proses perkembangan yang saling berinteraksi, diperlukan sekali kemampuan guru untuk mengimplementasikannya dalam setiap proses pembelajaran. Guru yang paham dengan perkembangan siswanya akan memberikan metode dan pendekatan pembelajaran yang tepat bagi siswanya tersebut sehingga perkembangan kognitif, bahasa dan emosional semakin berkembang dengan baik. Tulisan yang menggunakan metode studi pustaka ini menyarankan agar guru dapat menjadi motivator dan fasilitator sehinggga guru dapat mendorong perkembangan ketiga aspek ini dalam pembelajaran. Pendekatan yang dapat dilakukan oleh guru dalam pembelajaran terkait dengan perkembangan kognitif, bahasa dan sosioemosional siswa adalah pendekatan konstruktivis, pembelajaran kelompok, dan pembelajaran pengaturan diri. Selain itu ketiga aspek ini juga dapat dikembangkan melalui berbagai kegiatan ekstra kurikuler dan bimbingan rohani.
\end{abstract}

Kata Kunci : Perkembangan Kognitif, Bahasa, Sosioemosional, Pembelajaran

\section{Abstract}

This paper analyzes the process of learning development of children in their sudy in relation with the teacher's ability in implementing of these three stages of learning development. The process is divided into three important stages namely cognitive development, language development and socio-emotional development. These three process are connected each other. Furthermore, because each child has its own characteristics and uniqueness, these three developmental processes are needed to pay more attention by the teacher. The paper used content analysis of several books through library study method. From the literatures it has been known that the teacher's ability is important to implement these three stages in every learning process. Teachers who understand the development of their students will provide the right learning methods and approaches for these students, teacher can encourage the development of these three aspects; As a result, the cognitive, language and emotional development will develop well. It also suggested that the teacher can be a motivator and facilitator by using constructivist approaches, group learning, and self-regulation learning. In addition, these three aspects can also be developed through various extra-curricular activities and spiritual guidance.

Keyword: Learning development, Cognitive, Language, Socioemotional, Learning Process

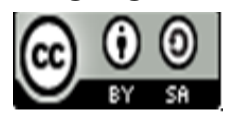

Received: October 9, 2018

Revised: December 28, 2018

Available Online: December 31, 2018

Jurnal Socius: Journal of Sociology Research and Education Vol. 5, No.2, Th. 2018

ISSN: Online 2442-8663 - Print 2356-4180 


\section{Pendahuluan}

Mempelajari perkembangan kognitif, bahasa dan emosional anak merupakan hal yang penting dalam dunia pendidikan terutama dalam pembelajaran. Semakin memahami perkembangan anak, maka semakin tepat dalam menangani dan mengajari siswa. Pengajaran yang diberikan kepada siswa harus berdasarkan tingkat yang tidak terlalu sulit dan tidak terlalu menegangkan, atautidak terlalu mudah dan menjemukan. Menurut Dierking (2015), ketepatan dalam memberi cara dan suasana yang menyenangkan bagi siswa membuat mereka semakin termotivasi untuk belajar. Kesenangan siswa terhadap suasana pembelajaran menimbulkan kemampuan siswa untuk berpikir sehingga aspek kognif siswa mengalami perkembangan. Runesson (2015) juga mengkaji bahwa belajar kognitif juga dapat mempelajari perilaku yang tidak dapat diamati. Kajian tersebut dilakukan oleh para ahli psikologi dengan menggunakan analisis teori belajar kognitif.

Banyak siswa yang bermasalah dalam belajar, seperti tidak mau belajar di kelas, tidak mau membuat tugas rumah, ribut, sering tidak mendengarkan guru, rendah diri, bermasalah dengan teman, motivasi belajar rendah dan lain sebagainya sehingga berdampak terhadap hasil belajar yang diperoleh oleh siswa tersebut dengan hasil yang tidak memuaskan. Permasalahanpermasalahan tersebut terjadi karena guru kurang memahami kondisi siswanya. Padahal, dalam pembelajaran yang dilaksanakan oleh guru harus sesuai dengan perkembangan kognitif, bahasa dan emosional anak. Untuk itu diperlukan suatu pemahaman dengan skema berpikir yang tepat dan jelas dalam memahami tentang perkembangan kognitif, bahasa dan emosional dalam pembelajaran. Tulisan ini akan menjelaskan bagaimana perkembangan kognitif, bahasa dan sosioemosional ? serta bagaimana implikasi ketiga aspek tersebut dalam pembelajaran?

\section{Metode Penelitian}

Metode penelitian yang digunakan untuk mengumpulkan informasi adalah menggunakan metode studi pustaka.Metode studi pustaka adalah mengumpulkan informasi dari buku-buku dan literatur lainnya yang terkait dengan masalah dan tujuan penelitian. Buku-buku dan literatur lain adalah sebagai sumber data yang akan diolah dan dianalisis. Penelitian dilakukan dengan menelaah dan membandingkan sumber kepustakaan untuk memperoleh data yang bersifat teoritis. Tujuan dari metode ini untuk membentuk sebuah landasan teori (Arikunto, 2006). Dari berbagai buku dan literatur relevan tersebut penulis dapat memecahkan masalah yang diteliti.

\section{Pembahasan}

Perkembangan kognitif, bahasa dan emosional dapat mempengaruhi tumbuh kembang anak karena perkembangan ketiga aspek tersebut menunjukkan bagaimana siswa berpikir dan bersikap terhadap orang lain baik di lingkungan keluarga maupun di lingkungan sekolah. Dalam perkembangan kognitif siswa mulai berpikir rasional seiring dengan bertambahnya usianya. Perkembangan bahasa dapat melatih siswa dalam menggunakan bahasa yang dikenali dengan baik, sedang perkembangan sosioemosional membentuk kemampuan siswa untuk mampu berinteraksi dengan lingkungan dan bagaimana siswa menyikapi apa yang terjadi dengan lingkungannya (Kennedy \& Jeremy, 2016) khususnya di kelas pada saat proses belajar sedang berlangsung. Pada bagian pembahasan ini akan diuraikan bagaimana perkembangan ketiga aspek tersebut dan implikasinya dalam pembelajaran. 


\section{Perkembangan Kognitif}

Pengertian kognitif dapat dijelaskan oleh beberapa ahli seperti Drever, Piaget dan Chaplin. Drever dalam Nuraini (2004) menjelaskan bahwa kognitif adalah istilah umum yang meliputi pemahaman persepsi, imajinasi, penangkapan makna, penilaian dan penalaran. Selanjutnya dijelaskan juga oleh Piaget bahwa kognitif merupakan bagaimana anak beradaptasi dan menginterpretasikan objek dan kejadian-kejadian di sekitarnya (Santrock, 2008).

Perkembangan kognitif dalam tulisan ini dijelaskan dari pemikiran dua orang ahli psikologi Jean Piaget merupakan psikolog dari Swiss dan Lev Semionovich Vygotsky seorang psikolog dari Rusia. Karya Piaget menjadi dasar untuk memahami perkembangan anak. Bagi Piaget perkembangan bergantung sebagian besar pada manipulasi anak dan interaksi aktif dengan lingkungan. Pengetahuan berasal dari tindakan. Sedang karya Vygotsky memiliki dua gagasan utama yaitu 1) Perkembangan intelektual dipahami hanya dari sudut konteks sosio historis dan budaya yang dialami anak, dan 2) Perkembangan bergantung pada sistem tanda yang ada pada setiap orang saat mengalami pertumbuhan (Slavin, 2006).

Perkembangan merupakan suatu pola perubahan biologis, kognitif dan sosioemosional dari lahir hingga terus berlanjut sepanjang hayat. Dalam pendidikan, perkembangan anak sangat penting diperhatikan, karena setiap anak memiliki karakteristik dan keunikan sendiri, serta memiliki kecenderungan bawaan untuk berinteraksi dengan lingkungannya. Dengan demikian, pendidikan harus sesuai dengan perkembangan anak sehingga menjadi tidak terlalu sulit, tidak terlalu menegangkan, tidak terlalu mudah dan menjemukan bagi anak. Ada 3 proses perkembangan yang dilalui oleh anak, dan ketiga proses tersebut terjadi saling berinteraksi (Santrock, 2008). Pertama, proses biologis, yaitu perubahan dalam tubuh anak dan merupakan warisan genetik terkait dengan perkembangan otak, berat dan tinggi badan, perubahan kemampuan bergerak, dan perubahan hormon di masa puber. Kedua, proses kognitif, yaitu perubahan pemikiran, kecerdasan, dan bahasa anak. Proses ini memampukan anak dalam mengingat puisi, memecahkan soal matematika, menyusun strategi kreatif dan menghubungkan kalimat. Ketiga, proses sosioemosional, yaitu perubahan dalam hubungan anak dengan orang lain, perubahan emosi, dan perubahan kepribadian. Misalnya pengasuhan anak, perkelahian anak, perkembangan ketegasan anak perempuan dan perasaan gembira remaja.

Ada 4 tahap perkembangan kognitif menurut Piaget. Masing masing tahap berhubungan dengan usia dan kualitas kemajuan pikiran anak. Keempat tahap perkembangan kognitif tersebut terdiri dari : tahap sensorimotor, tahap pra-operasional, tahap operasional kongkret dan tahap operasional formal.

\section{Teori Perkembangan Kognitif Piaget}

Teori Piaget menjelaskan bahwa untuk memahami dunia anak secara aktif, anak-anak menggunakan skema (kerangka kognitif atau kerangka referensi) yang digunakan untuk mengorganisasikan dan menginterpretasikan informasi dan pengalaman mereka mulai dari skema yang sederhana hingga kompleks.

Menurut Piaget, ada dua proses yang dilakukan oleh anak dalam menggunakan dan mengadaptasikan skema yaitu : 1) Asimilasi yaitu suatu proses mental yang terjadi ketika seorang anak memasukkan pengetahuan baru ke dalam pengetahuan yang sudah ada; dan 2)

Jurnal Socius: Journal of Sociology Research and Education Vol. 5, No.2, Th. 2018 
Akomodasi yaitu suatu proses mental yang terjadi ketika anak menyesuaikan diri dengan informasi baru. Selain itu, secara kognitif anak-anak juga mengorganisasikan pengalamannya yang disebut dengan organisasi. Menurut Piaget organisasi adalah usaha mengelompokkan perilaku yang terpisah-pisah menjadi urutan yang lebih teratur.

Bagaimana anak bergerak dari satu tahap pemikiran ke tahap pemikiran selanjutnya ? Piaget menyebutnya dengan ekuilibrasi. Kondisi ini dialami si anak ketika terjadi konflik kognitif atau disekuilibrium. Misalnya anak akan mengalami kebingungan jika benda cair dituangkan ke dalam wadah yang berbentuk sempit dan tinggi. Kebingungan akan terjawab saat pikirannya semakin maju.

\section{Implikasi Teori Piaget dalam Pembelajaran}

Implikasi teori Piaget dalam pembelajaran adalah sebagai berikut:

1. Memberikan pandangan bahwa pendidikan hanya memperbaiki keahlian kognitif anak yang sudah muncul.

2. Menggunakan pendekatan konstruktivis yang menekankan bahwa anak-anak akan belajar lebih baik jika mereka aktif dan mencari solusi sendiri. Semua siswa sebaiknya diajarkan membuat penemuan, memikirkannya, dan mendiskusikannya bukan menyalin apa-apa yang dikatakan guru. Dierking (2015) menjelaskan bahwa pembelajaran yang menggunakan pendekatan konstruktivis ini dapat menganalisis masalah yang terkait dengan proses pembelajaran kolaboratif.

3. Guru sebagai fasilitator dalam belajar. Guru mendengar, mengamati dan mengajukan pertanyaan kepada siswa agar mereka mendapatkan pemahaman yang lebih baik. Mengajukan pertanyaan yang relevan merangsang siswa untuk berpikir dan menjelaskan jawaban mereka.

4. Guru mempertimbangkan pengetahuan dan tingkat pemikiran anak karena tidak datang dengan kepala kosong, tetapi telah memiliki banyak ide dan guru menginterpretasikan apa yang dikatakan siswa lalu memberikan respon yang sesuai dengan tingkat pemikiran siswa.

5. Melakukan penilaian terus menerus yaitu individu tidak dapat diukur dengan tes standar. Penilaian dilakukan secara individual dari diskusi yang merupakan hasil pemikiran mereka, penjelasan lisan dan tertulis sebagai alat evaluasi kemajuan.

6. Meningkatkan kemampuan intelektual siswa dengan melaksanakan pembelajaran secara alamiah. Anak tidak boleh didesak dan ditekan untuk menguasai banyak hal.

7. Menjadikan ruang kelas sebagai ruang eksplorasi dan penemuan. Guru menekankan bahwa siswa melakukan eksplorasi dan menemukan kesimpulan sendiri. Guru lebih banyak mengamati minat siswa dan partisipasi alamiah dalam aktifitas belajar. Menurut Ramdhani (2016) bahwa ruang kelas bila dijadikan sebagai ruang untuk melakukan eksplorasi dan penemuan ini, guru harus memberi kesempatan, kemudahan dan mengembangkan ide-ide siswanya sendiri. Siswa diajarkan secara sadar dengan menggunakan strategi sendiri untuk belajar.

\section{Teori Perkembangan Kognitif Vygotsky}

Berbeda dengan Piaget, Vygotsky perkembangan sangat terkait dengan masukan dari orang lain. Bagaimana perkembangan terjadi dalam pandangan Vygotsky ? Teori Piaget menjelaskan bahwa perkembangan anak mendahului pembelajaran. Artinya struktur kognisi tertentu perlu berkembang sebelum jenis-jenis pembelajaran tertentu dapat terjadi. Vygotsky menjelaskan bahwa pembelajaran mendahului perkembangan. Menurut Vygotsky (Slavin, 2006 : 60)

Jurnal Socius: Journal of Sociology Research and Education Vol. 5, No.2, Th. 2018 
pembelajaran melibatkan perolehan tanda-tanda yang didapatkan dari pengajaran dan informasi dari orang lain. Perkembangan terkait dengan pengaturan diri (self-regulation) yaitu kemampuan berpikir, berkomunikasi dan memecahkan masalah tanpa bantuan orang lain. Simbol-simbol yang telah diciptakan oleh budayalah yang akan membantu orang untuk berpikir, berkomunikasi dan memecahkan masalah tersebut (simbol/tanda yang telah diinternalisasi).

Ada 3 asumsi yang menjadi inti pandangan Vygotsky (Santrock, 2008 : 60) yaitu: 1) Keahlian kognitif anak dapat dipahami apabila dianalisis dan diinterpretasikan secara developmental dengan memeriksa asal usulnya dan transformasi dari bentuk awal ke bentuk selanjutnya; 2) Kemampuan kognisi dimediasi dengan kata, bahasa yang berfungsi sebagai alat psikologis untuk membantu dan mentransformasi aktivitas mental. Jadi, bahasa adalah alat penting karena membantu anak pada masa kanak-kanak awal (early childhood) untuk merancang aktivitas dan memecahkan masalah; 3)Kemampuan kognitif berasal dari relasi sosial dan dipengaruhi latar belakang sosiokultural. Misalnya dalam suatu kultur dalam pembelajaran berhitung dengan menggunakan komputer dan kultur lain pembelajaran berhitung menggunakan batu atau jari.

Konsep-konsep teori Vygotsky dalam menjelaskan perkembangan kognitif adalah sebagai berikut:

1. Zone of Proximal Development (ZPD) adalah sesuatu yang masih belum dapat dikerjakan (sulit) seorang anak sendirian tetapi dapat dikerjakan dengan bantuan orang dewasa yang memiliki kompeten. Zona perkembangan proximal ini menggambarkan tugas yang masih belum dipelajari seorang anak namun sanggup dipelajari pada waktu tertentu. (Santrock, 2008 :62).

2.Scafolding. Pembelajaran sosial adalah perancahan yang berarti menyediakan banyak dukungan kepada seorang anak selama tahap-tahap awal pembelajaran dan kemudian menghilangkan dukungan dan meminta anak memikul tanggung jawab yang makin besar begitu dia sanggup (Slavin, 2008 : 60-61).

3. Bahasa dan Pemikiran. Bahasa bukan hanya untuk komunikasi sosial, tetapi juga untuk merencanakan, memonitor perilaku dengan cara sendiri. Penggunaan bahasa untuk mengatur diri sendiri dinamakan dengan "pembicaraan batin" (Inner Speech) atau "pembicaraan privat" (private speech). Anak-anak harus menggunakan bahasa untuk berkomunikasi dengan orang lain sebelum mereka bisa fokus ke dalam pemikirannya sendiri. Anak-anak juga harus berkomunikasi ke luar dan menggunakan bahasa selama periode yang agak lama sebelum transisi dari pembicaraan eksternal ke pembicaraan batin (internal) terjadi. Anak yang banyak menggunakan private speech akan lebih kompeten secara sosial (Santrock, $2008: 63$ ).

4. Pembelajaran kerjasama. Teori Vygotsky mendukung penggunaan strategi pembelajaran kerja sama. Anak-anak yang bekerjasama saling membantu dalam belajar. Teman-teman yang bekerja dalam zona perkembangan proksimal mereka

5. Saling memberi contoh dan memungkinkan terjadinya pembicaraan batin sehingga dapat saling memahami dalam proses penalaran (Slavin, 2006 : 61). Dalam hal ini, sangat memungkinkan bagi guru untuk melakukan pendekatan pembelajaran secara kontekstual (Contextual Teaching Learning). Pendekatan pembelajaran secara kontekstual ini dijelaskan oleh Mano (2018) adalah suatu konsep belajar yang akan membantu guru menghubungan materi pembelajaran dengan situasi dunia nyata siswa dan akhirnya mendorong siswa untuk membuat hubungan antara pengetahuan yang mereka miliki dengan penerapannya dalam kehidupan sehari-hari. Dengan pendekatan ini siswa akan belajar dengan baik apabila yang

Jurnal Socius: Journal of Sociology Research and Education Vol. 5, No.2, Th. 2018 
mereka pelajari berhubungan dengan fenomena atau realita yang telah mereka ketahui. Saling memberi contoh merupakan penerapan bagi siswa untuk saling memahami fenomena dan realita yang pernah mereka alami. Dengan demikian, proses belajar akan produktif dan siswa aktif atau terlibat dalam proses pembelajaran.

Berdasarkan penjelasan di atas bahwa pemikiran Vygostky sangatlah tepat untuk digunakan dalam memahami kemampuan siswa dalam berkomunikasi saat pembelajaran. Untuk itu pembelajaran secara kolaboratif dan kontekstual dapat mendorong perkembangan komunikasi tersebut.

\section{Implikasi Teori Vygotsky dalam Pembelajaran}

Ada dua implikasi utama teori Vygotsky dalam pembelajaran yaitu :

1. Keinginan menyusun pembelajaran kerjasama (cooperative learning) di antara kelompokkelompok siswa yang mempunyai tingkat kemampuan yang berbeda-beda. Pengajaran pribadi oleh teman yang lebih kompeten dapat berjalan efektif meningkatkan pertumbuhan dalam zona perkembangan proksimal. Pembelajaran kerjasama lebih memudahkan siswa menemukan dan memahami konsep yang sulit karena mereka dapat saling berbicara membicarakan soal yang sulit dan mereka dapat belajar dari teman sebayanya tentang cara berpikir yang tepat.

2. Pendekatan pembelajaran yang menekankan perancahan (scaffolding) akan mengambil banyak tanggung jawab untuk pembelajaran siswa sendiri. Misalnya guru yang yang semula memimpin kelompok-kelompok kecil siswa untuk mengajukan pertanyaan tentang hal-hal yang dipelajari secara bertahap mengalihkan tanggung jawab diskusi tersebut kepada siswa.

\section{Perkembangan Bahasa}

Santrock (2008) mengemukakan bahwa bahasa merupakan suatu bentuk komunikasi secara lisan, tulisan atau tanda yang didasarkan pada sistem simbol. Semua bahasa mengikuti aturan fonologi, morfologi, sintaksis, semantik dan pragmatis. Bahasa yang diucapkan terdiri dari suara atau fonem.

Bahasa memainkan peran utama dalam perkembangan kognisi anak. Oleh karena itu anakanak harus didorong untuk mengembangkan bahasa. Perkembangan bahasa melalui beberapa tahap (Santrock, 2008 : 67-75) yaitu : Celoteh yang dimulai pada usia 3 hingga 6 bulan. Mengucapkan kata pertama pada usia 10 hingga 13 bulan dan mulai memadukan dua kata pada usia 24 bulan seperti "itu buku", "mama jalan", dan "cium papa".

Pada masa kanak-kanak mereka makin mampu menghasilkan semua suara bahasa bahkan menghasilkan konsonan yang kompleks. Kosa kata anak dari usia 6 tahun berkisar 8.000 sampai 14.000 kata. Sejak usia 12 bulan telah menguasai 5 sampai 8 kata baru setiap hari antara usia 1-6 tahun. Setelah 5 tahun belajar penyerapan anak pada usia 6 tahun tidak melambat. Rata -rata anak pada usia ini menguasai 22 kata baru setiap hari.

Anak yang berusia 6 tahun lebih lancar berbicara dari anak usia 2 tahun, karena ada beberapa perubahan aspek pragmatis di masa prasekolah. Pada usia 3 tahun, anak meningkatkan kemampuan berbicaranya tentang sesuatu yang tidak hadir secara fisik, masa lalu, masa depan, apa yang akan dimakan besok dan berbicara dengan orang yang berbeda-beda. Mereka meningkatkan penguasaan karakteristik yang disebut "displacement"

Jurnal Socius: Journal of Sociology Research and Education Vol. 5, No.2, Th. 2018 
Pada masa kanak-kanak periode menengah dan akhir( middle and late childhood) terjadi perubahan cara berpikir anak tentang kata. Pada tahap ini biasanya memberikan kata yang mengikuti kata tersebut dalam kalimat. Misalnya diminta menjawab "anjing" dijawab dengan "mengonggong", "makan" di jawab "sarapan".

Pada usia 7 tahun anak-anak merespon dengan kata yang golongannya sejenis, seperti "anjing" dengan "kucing" atau "kuda" dan "makan dengan "minum". Anak-anak yang masuk sekolah dasar dengan kosa kata yang sedikit akan mengalami kesulitan saat belajar membaca. Keahlian penalaran logis dan analitis membantu mereka dalam konstruksi kata untuk perbandingan dan penggunaan pendapat subjektif.

Pada masa remaja, kosa kata bertambah dengan kata-kata yang makin abstrak dan tata bahasa yang makin kompleks. Pada masa remaja akhir(late adolescent) seseorang dapat mengapresiasikan karya sastra dewasa secara lebih baik.

\section{Teori Perkembangan Bahasa}

Salah satu yang dapat menjelaskan tentang perkembangan bahasa adalah teori natifisme.Yang menjadi ciri dari khas dari teori ini adalah lingkungan tidak memberikan kontribusi terhadap pengetahuan manusia. Kesuskesan preoses penerimaan ilmu ditentukan oleh hereditas individu itu sendiri. Seorang anak memiliki bakat yang telah dibawa sejak lahir. Teori ini digunakan untuk meneliti kemampuan bahasa seseorang. Menurut Noam Chomsky, bahasa itu terlalu rumit untuk dipelajari jika hanya mengandalkan metode peniruan. Tujuan dari teori ini adalah menemukan bakat terpendam yang dimiliki, mengasah kompetensi diri, dan memotivasi individu untuk menentukan pilihan. Dalam diri manusia sudah ada nnate mechanismnn yaitu bahasa seseorang ditentukan oleh genetika. Sejak lahir manusia memiliki alat penguasaan atau pemerolehan bahasa LAD (Language Acquisation Device). LAD memperoleh input dari lingkungan dan dianggap bagian fisiologis dari otak untuk mengolah masukan dan menentukan mana yang dikuasai lebih dulu (Crain, 2007).

Crain juga menjelaskan teori lain yang terkait dengan perkembangan bahasa adalah teori interaksionisme. Teori ini berpandangan bahwa pemerolehan bahasa adalah hasil dari interaksi antara kemampuan mental pembelajaran dan lingkungan bahasa. Pemerolehan bahasa terkait dengan adanya interaksi masukan dan kemampuan internal yang dimiliki pembelajar. Tanpa adanya masukan yang sesuai dan tidak memungkinkan bagi si anak untuk dapat menguasai bahasa tertentu secara otomatis.

Teori lain menurut Crain (2007) adalah teori kognitivisme dari Jean Piaget. Menurut Piaget, perkembangan bahasa ditentukan oleh urutan-urutan perkembangan kognitif. Perkembangan bahasa tergantung pada kemampuan kognitif tertentu, pengolahan informasi dan motivasi. Teori ini sebenarnya berupaya menggabungkan peran lingkungan dan faktor bawaan, tetapi tetap menekankan pada aspek berpikir logis (the power of logical thinking).

\section{Implikasi Teori Perkembangan Bahasa dalam Pembelajaran}

Implikasi teori perkembangan bahasa dapat dilihat implikasinya dalam pembelajaran yaitu sebagai berikut:

1. Guru harus mampu memunculkan dan memotivasi semua bakat yang dimiliki oleh siswa di sekolah. Ini bertujuan untuk mengoptimalkan bakat yang dimiliki siswa dan setelah ia 
mengetahui bakatnya, maka siswa bisa mengembangkan dan berdampak terhadap kemajuan diri siswa .

2. Guru mendorong siswa untuk berkompetisi. Kompetisi dapat membuat siswa lebih kreatif dan inovatif dalam mengembangkan bakatnya. Siswa yang berkompeten dapat bersaing dengan siswa lain dalam menghadapi tantangan zaman yang semakin kompetitif saat ini.

3. Guru mendorong siswa untuk menentukan pilihan. Diharapkan dari pilihan siswa, ia menjadi seorang yang lebih bijaksana, berkomitmen dan berpegang tegung dengan pilihan serta berkeyakinan dengan pilihannya itu adalah yang terbaik untuk dirinya.

\section{Perkembangan Sosioemosional}

Sosioemosional dapat diartikan sebagai perubahan yang terjadi pada diri setiap individu dalam ranah afektif yang berkaitan dengan setiap kondisi atau perilaku individu.Perkembangan sosioemosional merupakan kemampuan peserta didik dalam berinteraksi dengan lingkungannya dan bagaimana mereka menyikapi hal-hal yang terjadi di lingkungannya tersebut. Hal ini ditandai dengan adanya perluasan hubungan baik dengan keluarga, maupun dengan teman sebayanya sehingga memberi ruang bagi mereka untuk berinteraksi, bersosialisai dan bekerjasama dengan orang lain. Perkembangan sosioemosional menurut Santrock (2008) terkait dengan perkembangan diri dan perkembangan moral. Berikut penjelasan kedual hal itu.

Perkembangan sosioemosional terkait dengan perkembangan diri dan perkembangan moral. Ada dua aspek penting tentang diri yaitu harga diri dan (self-esteem) dan identitas diri. Santrock (2008) menjelaskan bahwa penghargaan diri (self-esteem) adalah pandangan keseluruhan dari individu tentang dirinya sendiri. Penghargaan diri disebut juga dengan martabat diri (self-worth) atau gambaran diri (self-image). Seseorang yang rendah diri karena tidak diberinya dukungan emosional dan penerimaan sosial yang memadai. Rendah diri yang terus bertahan menjadi suatu problem yang serius dan bisa mengakibatkan prestasi yang buruk, depresi, gangguan makan dan tindakan kejahatan.

Aspek penting lain dari diri adalah identitas.Bagi remaja perkembangan identitas merupakan pencarian jawaban atas pertanyaan seperti : siapa aku? seperti apa aku? Apa yang akan aku lakukan dalam hidup ini? Untuk memahami identitas bedakanlah eksplorasi dengan komitmen. Eksplorasi adalah pencarian identitas alternatif yang bermakna, sedang komitmen adalah penerimaan personal pada satu identitas dan menerima apapun implikasi dari identitas tersebut. Eksplorasi dan komitmen ini digunakan untuk mengklasifikasikan diri berdasar 4 tipe identitas yaitu :

1. Identity diffusion : ketika individu belum mengalami krisis atau belum membuat komitmen.

2. Identity foreclosure : terjadi saat individu membuat komitmen tetapi belum mengalami krisis.

3. Identity moratorium : terjadi ketika individu berada di tengah-tengah krisis tetapi komitmen mereka tidak ada atau baru didefenisikan secara samar-samar.

4. Identity achievement : terjadi ketika individu telah mengalami krisis dan telah membuat komitmen.

\section{Teori Perkembangan Sosioemosional}

Teori yang difokuskan dalam tulisan ini untuk menjelaskan perkembangan sosioemosional yaitu teori ekologi dari Urie Bronfenbrenner dan teori perkembangan rentang hidup (life-span) dari Erikson (Santrock, 2008). Teori ekologi Bronfenbrenner memfokuskan pada konteks sosial anak tinggal dan orang-orang yang saling mempengaruhi perkembangan anak. Teori ini terdiri

Jurnal Socius: Journal of Sociology Research and Education Vol. 5, No.2, Th. 2018 
dari lima sistem lingkungan yang terdiri dari mikrosistem, mesosistem, ekosistem, makrosistem, dan kronosistem.

Mikrosistem merupakan setting dimana individu lebih banyak menghabiskan waktu seperti di keluarga, teman sebaya, sekolah dan tetangga. Dalam hal ini, seseorang bukan sebagai penerima pasif dalam setting, tetapi orang yang berinteraksi secara timbal balik dengan orang lain dan membantu mengkonstruksi setting.

Mesosistem adalah kaitan antar-mikrosistem. Misalnya hubungan pengalaman siswa dalam keluarga dengan pengalaman di sekolah dan antara keluarga dengan teman sebaya. Ekosistem terjadi ketika pengalaman di setting lain mempengaruhi pengalaman siswa dan guru dalam konteks mereka sendiri. Contohnya adalah dewan komite sekolah dan pengawas sekolah berperan kuat dalam menentukan kualitas pembelajaran dan sarana prasarana di sekolah.

Makrosistem merupakan kultur yang lebih luas yang mencakup peran etnis dan faktor sosial ekonomi dalam perkembangan anak. Misalnya kultur di Minangkabau yang memiliki falsafah Adat Basandi Syarak, Syarak Basandi Kitabullah mengharuskan siswa di sekolah menggunakan pakaian muslim dalam belajar. Sementara sekolah di Jawa tidak mengharuskan berpakaian muslim di sekolah dalam belajar. Sementara itu keadaan sosial ekonomi seperti kondisi kemiskinan dapat mempengaruhi perkembangan siswa dan merusak kemampuan belajar anak meskipun mereka tekun dan ulet dalam belajar.

Kronosistem adalah kondisi sosiohistoris dari perkembangan anak. Misalnya siswa saat ini tumbuh dalam kemajuan sistem teknologi informasi yang penuh dengan berbagai media. Bronfenbrenner memperhatikan dua hal penting terkait sistem lingkungan ini, yaitu anak yang hidup dalam kemiskinan terutama anak yang tumbuh dengan orang tua yang tunggal (single parent) dan terjadinya penurunan nilai-nilai.

Selanjutnya, teori perkembangan rentang hidup (life span) dari Erik Erikson menjelaskan bahwa perkembangan seseorang melalui rentang hidup dalam 8 tahapan. Masing-masing tahap terdiri dari tugas perkembangan yang dihadapi individu yang mengalami krisis. Semakin sukses seseorang mengatasi krisis, maka semakin sehat psikologi individu tersebut. Masing-masing tahap memiliki sisi positif dan negatif. Tahapan dari rentang hidup itu adalah sebagai berikut:

1. Kepercayaan versus ketidakpercayaan yaitu perkembangan kepercayaan membutuhkan pengasuhan yang hangat dan bersahabat sehingga memberikan rasa nyaman. Ketidakpercayaan tumbuh jika bayi diabaikan atau diperlakukan buruk.

2. Otonomi versus malu dan ragu yaitu tahap dimana bayi menemukan tindakannya sendiri. Jika bayi dihukum atau dibatasi, maka mereka akan mengembangkan rasa malu.

3. Inisiatif versus rasa bersalah adalah tahap dimana pada masa kanak-kanak awal yang telah merasakan tantangan hidup dan harus aktif dan bertujuan agar dapat mengatasi tantangan tersebut. Mereka harus diberi tanggung jawab dan mengembangkan rasa bersalah apabila tidak bertanggung jawab.

4. Upaya versus inferioritas. Tahap ini terjadi pada usia sekolah dasar. Pada tahap ini anak menggunakan energinya untuk menguasai pengetahuan dan keterampilan intelektual Bahayanya pada masa ini adalah munculnya rasa rendah diri, ketidakproduktifan, dan inkompetensi.

5. Identitas versus kebingungan. Tahap ini adalah masa remaja dimana mereka mencari tahu jati diri, makna diri dan kemana tujuannya. Mereka diberi kesempatan untuk mengeksplorasi diri untuk memahami identitas dirinya tersebut.

Jurnal Socius: Journal of Sociology Research and Education Vol. 5, No.2, Th. 2018 
6. Intimasi versus isolasi. Tahap masa dewasa awal yang membangun hubungan positif dengan orang lain. Kesepian bisa membayangi hidupnya.

7. Generativitas versus stagnasi adalah masa dewasa pertengahan (usia 40-50 an) yang membantu mentransfer mengembangkan hidup yang berguna kepada generasi berikutnya (generativitas) dan mendeskripsikan stagnasi jika tidak dapat melakukan apa-apa untuk generasi berikutnya.

8. Integritas versus putus asa. Tahap ini berhubungan dengan masa dewasa akhir pada usia 60 tahun sampai meninggal. Orang tua merenungi kembali hidupnya dan memikirkan apa yang telah dilakukan. Jika evaluasi retrospektifnya positif, maka akan memunculkan integritas, tetapi jika renungannya negatif, maka akan terjadi putus asa.

\section{Implikasi Teori Perkembangan Sosioemosional dalam Pembelajaran}

Implikasi teori Brofenbrenner dalam mendidik anak adalah sebagai berikut:

1. Pandanglah anak sebagai sosok yang terlibat dalam berbagai sistem lingkungan seperti sekolah, guru, orang tua, saudara kandung, tetangga, teman sebaya, media, agama, kultur dan anak akan dipengaruhi sistem-sistem tersebut.

2. Memperhatikan hubungan antara sekolah dan keluarga, baik secara formal maupun informal.

3. Menyadari pentingnya arti komunitas, status sosial ekonomi dan kultur dalam perkembangan anak.

Implikasi teori Erikson dalam pembelajaran adalah sebagai berikut:

1. Mendorong siswa untuk berinisiatif dengan memberikan tugas-tugas yang tepat untuk perkembangan siswa.Jangan sampai siswa kesal karena duduk dalam waktu yang lama.

2. Mempromosikan usaha belajar untuk anak-anak sekolah dasar. Guru penting memotivasi siswa untuk menguasai pengetahuan, rasa ingin tahu dan bersikap toleran terhadap kesalahan yang wajar.

3. Mengajak remaja untuk mengeksplorasi identitas dirinya yang multidimensi. Mintalah mereka menulis esai siapa diri mereka dan apa yang akan mereka lakukan dalam hidup.

4. Mengkaji diri kita sebagai guru dengan 8 tahapan Erikson sehingga dapat menunjukkan pada usia dimana dan isu yang penting dalam usia tersebut.

5. Mengambil karakteristik yang bermanfaat dari tahap Erikson yaitu dapat dipercaya, inisiatif, menjadi model dalam penguasaan materi pembelajaran dan memiliki motviasi untukberkontribusi terhadap generasi selanjutnya.

Implikasi dalam pembelajaran terkait dengan perkembangan diri dapat dilakukan dengan pendekatan pembelajaran pengaturan diri. Pendekatan ini menganggap bahwa siswa mempunyai pengetahuan tentang strategi pembelajaran yang efektif, bagaimana dan kapan menggunakannya. Siswa dapat mengurai soal yang rumit menjadi langkah-langkah yang sederhana dan mencari sendiri solusi alternatifnya. Beberapa hal penting terkait dengan pembelajaran pengaturan diri dapat dilihat sebagai berikut :

1. Identifikasi penyebab rendah diri dan area kompetensi yang penting bagi diri. Apakah karena konflik keluarga, prestasi yang buruk atau lainnya. Penerimaan sosial dari teman dan dukungan guru merupakan hal penting bagi rasa harga diri siswa.

2. Memberi dukungan emosional dan penerimaan sosial. Bisa dilakukan oleh konselor, guru BK, dukungan orang tua dan teman sebaya.

Jurnal Socius: Journal of Sociology Research and Education Vol. 5, No.2, Th. 2018 
3. Membantu anak mencapai tujuan atau berprestasi dengan cara membantu mengembangkan keahlian, keterampilan dan prestasi siswa.

4. Mengembangkan keterampilan mengatasi masalah. Ketika anak menghadapi problem bagaimana bisa mengatasinya bukan menghindarinya, maka rasa harga diri akan naik

Selain perkembangan diri, perkembangan moral juga berkaitan dengan kognitif, behavioral, dan emosional. Domain kognitif terkait dengan bagaimana siswa menalar aturan perilaku etis. Domain behavioral fokusnya adalah bagaimana siswa berperilaku secara aktual bukan pemikirannya dan domain emosional terkait dengan bagaimana siswa merasakan secara moral.

Teori Kohlberg menjelaskan perkembangan moral yang terdiri dari tiga level utama dengan dua tahap pada setiap level. Konsep penting memahami teorinya adalah adanya internalisasi yaitu perubahan perkembangan dari perilaku yang dikontrol secara eksternal dan internal (Santrock, $2008:$ 118-119) adalah :

1. Preconventional reasoning (penalaran prakonvensional) adalah level terbawah. Pada level ini anak patuh karena dikontrol oleh hukuman dan ganjaran eksternal.

2. Conventional reasoning (penalaran konvensional) adalah tahap kedua atau menengah. Pada tahap ini anak patuh secara internal pada standar tertentu seperti orang tua atau aturan sosial.

3. Postconventional reasoning (penalaran post konvensional) adalah level tertinggi. Pada tahap ini moralitas telah sepenuhnya terinternalisasi dan tidak berdasarkan standar eksternal.

Implikasi perkembangan sosioemosional terkait dengan perkembangan moral adalah menggunakan pendidikan moral melalui kurikulum tersembunyi. Kurikulum tersembunyi dengan adanya suasana moral yang diciptakan melalui aturan sekolah, aturan kelas, orientasi moral dari guru dan administrasi sekolah dan teks materi pembelajaran. Selain kurikulum tersembunyi pendekatan langsung yang dilakukan dalam pendidikan moral ini adalah melakukan pendidikan karakter. Pendidikan karakter mengajarkan siswa tentang pengetahuan moral dasar untuk mencegah agar siswa tidak melakukan tindakan tidak bermoral, membahayakan orang lain dan dirinya sendiri. Misalnya melakukan tindakan mencuri, berbohongdan menipu. Dalam pendidikan karakter, sekolah harus memiliki aturan moral yang jelas dan dikomunikasikan secara jelas kepada siswa. Setiap pelanggaran harus ada sanksi (Santrock, 2008 : 121-124). Beberapa tindakan dan cara yang dilakukan dalam pendidikan moral dan pendidikan karakter kepada siswa adalah ;

1. Menghargai dan tekankan konsideransi kebutuhan orang lain. Hal ini bertujuan agar siswa bisa memahami perasaan orang lain dan aktivitas membantu orang lain.

2. Guru menjadi contoh perilaku social, siswa meniru apa yang dilakukan oleh gurunya.

3. Beri label dan identifikasi perilaku prososial dan antisosial. Perilaku prososial seperti kamu banyak membantu, itu sangat bagus dan perilaku antisosial seperti itu tidak bagus, bagaimana perasaanmu jika kertasmu disobek?

4. Sebutkan niat positif kepada tindakan yang positif seperti kamu mau berbagi sebab kamu suka menolong orang lain.

5. Perhatikan dan dorong perilaku secara sosial, positif dan jangan terlalu banyak menggunakan ganjaran eksternal.

6. Bantu anak untuk mengambil sikap dan memahami perasaan orang lain.

7. Gunakan strategi disiplin yang positif.

8. Pimpin diskusi tentang interaksi prososial.

Jurnal Socius: Journal of Sociology Research and Education Vol. 5, No.2, Th. 2018 
9. Kembangkan proyek kelas dan sekolah yang bisa meningkatkan altruisme.

\section{Penutup}

Dalam dunia pendidikan, memahami anak harus menggunakan skema berpikir yang tepat dan jelas. Pendidkan harus sesuai dengan perkembangan kognitif, bahasa dan emosional anak, terutama dalam pembelajaran. Perkembangan kognitif menurut Piaget tergantung pada sebagian besar pada manipulasi anak dan interaksi aktif dengan lingkungan. Vygotsky melihat perkembangan kognitif berdasarkan pada dua gagasan utama yaitu perkembangan intelektual terkaitdengan konteks sosio historis dan budaya, dan sistem tanda seseorang saat mengalami pertumbuhan. Perkembangan bahasa menggunakan teori natifismeyaitu lingkungan tidak memberikan kontribusi terhadap pengetahuan manusia, teori interaksionisme yang berpandangan bahwa pemerolehan bahasa adalah hasil dari interaksi antara kemampuan mental pembelajaran dan lingkungan dan teorikognitivisme yang berupaya menggabungkan peran lingkungan dan faktor bawaan, tetapi tetap menekankan pada aspek berpikir logis (the power of logical thinking)

Perkembangan kognitif dan bahasa siswa dapat dikembangkan dengan adanya peran guru sebagai fasilitator dan motivator, melaksanakan pembelajaran kerjasama, pendekatan konstruktivis, pembelajaran pengaturan diri, kegiatan ekstra kurikuler dan bimbingan rohani.Perkembangan sosioemosional dapat dikaji dengan teori perkembangan ekologi Bronfenbrenner dan teori perkembangan rentang hidup Erikson. Kedua teori ini dipilih karena cukup komprehensif dalam membahas konteks sosial dimana anak berkembang dan perubahan dalam perkembangan sosioemosional. Perkembangan emosional dapat dibangun dalam proses pembelajaran dengan menggunakan kurikulum tersembunyi melalui aturan sekolah dan pendidikan karakter untuk mencegah siswa agar tidak melakukan perilaku yang tidak bermoral dan merugikan orang lain.

\section{Daftar Pustaka}

Adam, Sumartin. (2014). Aplikasi Teori Perkembangan Bahasa Menurut Vygotsky dalam Pendidikan. Jurnal TADBIR : Jurnal Manajemen Pendidikan Islam, 2(2), 252-258.

Arikunto, S. (2006). Metode Penelitian Kualitatif. Jakarta: Bumi Aksara.

Crain, William. (2007). Teori Perkembangan/Konsep dari Aplikasi. Yogyakarta: Pustaka Pelajar.

Dierking, Lynn. (2015). Learning Theory and Learning Styles: An Overview. Journal of Museum Education. 16(1), 4-9.

Gunarsa, Singgih dan Ny. Gunarsa. (1991). Psikologi Remaja. Jakarta: PT. BPPK Gunung Mulia.

Gunardi, Winda. (2008). Metode Perkembangan Perilaku dan Kemampuan Dasar Usia Dini. Jakarta: UT.

Jurnal Socius: Journal of Sociology Research and Education Vol. 5, No.2, Th. 2018 
Kennedy, Emma-Kate \& Jeremy J. Monsen. (2016). Evidence-Based Practice in Educational and Child Psychology: Oppotunities for Practitioner-Researchers Using Problem Based Methodology. Journal Educational \& Child Psychology. 33(3), 11-25.

Nurani, Yuliani dan Sujiono. (2004). Metode Perkembangan Kognitif. Jakarta: UT.

Mano, Michelle S.M. (2018). The Relationship Between Contextual Characteristics and The Integrational Correlation of Education in Developing Countries. International Journal of Education Development. Elsevier, 62(1), 22-37.

Ramdhani, Rekha Budi. (2016). The Develpment of Edutaintment Learning Model in Social Science Education. International Journal Pedagogy Social Studies. 1(2), 265-274.

Runesson, U. (2015). Pedagogycal and Learning Theories and The Improvement and Development of Lesson Studies. International Journal for Lesson and Learning Studies. DIVA. 4(3), 186-193.

Santrock, John W. (2008). Psikologi Pendidikan. Jakarta: Kencana.

Slavin, Robert E. (2008). Psikologi Pendidikan: Teori dan Praktik. Jilid 1. Edisi Kedelapan. Jakarta: PT Indeks.

Slavin, Robert E. (2011). Psikologi Pendidikan: Teori dan Praktik. Jilid 2. Edisi Kesembilan. Jakarta: PT. Indeks.

Woolfolk, AE.end Nicolich,LM. (1984). Educational Pschology For Teachers, New Jersey: Prentice-Hall,Inc. 